\title{
The Implementation of Islamic Governance Disclosure: An Empirical Study of Indonesian Islamic Banking
}

\section{Agus Wahyudin, Fachrurrozie, Ahmad Nurkhin, and Satsya Yoga Baswara}

Faculty of Economics, Universitas Negeri Semarang, Indonesia

\section{Abstract}

There have been several research related to good corporate governance (GCG). This study aims at examining more deeply the implementation of Islamic Governance Disclosure (IGD) in Islamic banks in Indonesia. The research method used is descriptive quantitative research. The research population is Islamic banks in Indonesia. The sampling method is purposive sampling with the criteria of Islamic commercial banks having assets of more than 20 trillion rupiah on December 31, 2017 and their annual reports for the observation period were accessed. The research sample obtained four Islamic banks, namely, Bank Muamalat, Bank Syariah Mandiri, BNI Syariah, and

Corresponding Author:

Ahmad Nurkhin

ahmadnurkhin@mail.unnes.ac.id

Received: 29 January 2019

Accepted: 27 February 2019

Published: 24 March 2019

Publishing services provided by Knowledge E

(c) Agus Wahyudin et al. This article is distributed under the terms of the Creative Commons

Attribution License, which permits unrestricted use and redistribution provided that the original author and source are credited.

Selection and Peer-review under the responsibility of the $3 \mathrm{rd}$ ICEEBA Conference Committee.
BRI Syariah. The observation period was 3 years, 2015-2017. The writer employed documentation with a checklist tool developed from previous research and regulations in collecting the data. Then, the writer used content analysis in analyzing data. The analysis is used to calculate the index of IGD disclosure and analyze the extent of disclosure, consisting of three main index such as Shariah Supervisory Board (SSB) disclosure index, SSB report disclosure index, and zakat disclosure index. The results showed that the four Islamic banks had a good IGD index for past three years. The IGD index of BRI Syariah was fluctuating and was the lowest in 2015 and 2017. The IGD index of Bank Syariah Mandiri and BNI Syariah were the highest and most consistent for three consecutive years. The IGD index of Bank Muamalat was consecutively 0.78 in 2015, 0.81 in 2016, and 0.69 in 2017. The IGD index of Bank Syariah Mandiri and BNI Syariah were the same, which was 0.78 in 2015, 0.81 in 2016, and 0.78 in 2017. While the IGD of BRI Syariah was 0.67 in 2015, 0.83 in 2016, and 0.69 in 2017.

Keywords: Islamic governance disclosure, Sharia supervisory board, Islamic bank

\section{Introduction}

Studies and research on good corporate governance (GCG) are still interesting. GCG is a mechanism aimed at corporations to improve performance. Wibowo (2010) argues that GCG is needed to encourage the creation of an efficient, transparent market and consistent with the laws and regulations. 
Research so far includes assessing the effect of GCG (with various measures or proxies) on company performance or company value (Agustiningsih, Sulistyaningsih, \& Purwanto, 2016; Arora \& Sharma, 2016; Asrori, 2014; Malik \& Makhdoom, 2016; Nurkhin, Mukhibad, Kiswanto, \& Rohman, 2018; Nurkhin, Wahyudin, \& Fajriah, 2017; Wahyudin \& Solikhah, 2017). Other researchers examine the relationship of GCG to corporate social responsibility (Nurkhin, 2010; Said, Joseph, \& Mohd Sidek, 2017). GCG measurements also vary, including using a proxy mechanism for GCG or GCG index.

Some researchers have conducted a study of GCG disclosure (Gandia, 2008; Green \& Graham, 2015; Hassan, 2012; Ntim, Opong, Danbolt, \& Thomas, 2012; Parsa, Chong, \& Isimoya, 2007; Qu \& Leung, 2006; Tsamenyi, Enninful-Adu, \& Onumah, 2007). Qu \& Leung (2006) has conducted research to uncover GCG disclosure in public companies in China. Tsamenyi et al. (2007) examined the factors that influence GCG disclosure. He found that ownership structure, dispersion of shareholding, and firm size have a significant effect on GCG disclosure.

Parsa et al. (2007) examined the extent of compliance with governance regulations by small and medium enterprises (SMEs) listed in the alternative investment market (AIM). An average of around $50 \%$ has been revealed by governance items by MSMEs registered with AIM. In large companies, there is a positive influence on the number of non-executive directors on the extent of GCG disclosure. Gandia (2008) examined the practice of GCG disclosure over the internet in public companies in Spain. And also investigate the factors that influence it. Companies that have the highest score on the transparency aspect prefer using internet as a media for disclosing information on corporate governance. Other results indicate the level of disclosure depends on the level of the company, company age, visibility, and the reality associated with the information and communication services industry.

Ntim et al. (2012) developed CG disclosure index consisting of 50 CG provisions from the 2002 King Report. And examine the factors that influence CG disclosure in the post- Apartheid South African corporations. He found that block ownership was negatively related to GCG disclosure, while board size, audit firm size, cross-listing, CG committee presence, government ownership and institutional ownership had a positive effect on voluntary CG disclosures. Hassan (2012) extensively extends corporate governance reporting to companies listed in the United Arab Emirates (UAE). Overall, broad governance disclosures are found to be the same for all economic sectors in the UAE.

Within the framework of companies in Indonesia, Djakman, Siregar, \& Harahap (2017) examine the practice of GCG disclosure, especially in the disclosure of audit committees 
and internal audit. The results of his research show that the disclosure of these two things is still relatively low in 2012 and 2013.

Islamic banks also implement GCG in its operations. Some researchers call it shariah corporate governance or shari'ah governance (Ginena, 2014; Z. Hasan, 2010; Muneeza \& Hassan, 2014). Other researchers introduce it to Islamic corporate governance (Bhatti \& Bhatti, 2010; Choudhury \& Hoque, 2006; Elghuweel, Ntim, Opong, \& Avison, 2017). The concept has been modified because it must comply with Islamic principles. We know that the operations of Islamic banks must comply with Shariah or Islamic law. Wibowo (2010:127) states that good governance is a very universal principle, so that it becomes a reference for all religious communities, and can be found in cultural cultures everywhere. The thing that distinguishes GCG practices in a country is GCG as a system, because it must always adjust to the legal system, the state and development of progress, as well as the culture of the nation itself.

Shari'ah corporate governance is different from conventional GCG because both objectives are very unique (Alnasser \& Muhammed, 2012; Muneeza \& Hassan, 2014). Within the framework of corporate governance, decision-making for companies must be based on shura or consultation (Muneeza \& Hassan, 2014). Hassan (2009) proposed two structures in shari'ah corporate governance, namely the monotheism and shura approach and the stakeholder approach. Similar to the implementation of GCG in conventional banks, Shariah Commercial Bank GCG disclosures refer to Bank Indonesia Regulation Number 11/33/PBI/2009 which is still used today by Islamic Commercial Banks (Ardhanareswari, 2017).

Darmadi (2013) was the first researcher to try to uncover the practice of GCG in Islamic banks in Indonesia. He uses Corporate Governance Disclosure Index (CGDI) to assess the level of disclosure in seven Islamic public banks in Indonesia. Corporate governance mechanisms in CGDI are Shariah Supervisory Board, the Board of Commissioners, the Board of Directors, board committees, internal control and external audit, and risk management. The results showed that Bank Muamalat and Bank Syariah Mandiri, which are the two largest and oldest Islamic banks, obtained the highest scores compared to other Islamic banks. Disclosures about the board of directors and risk management are found to be very high. While disclosure related to internal supervision and our council tends to be weak.

Abdullah, Percy, \& Stewart (2013) compared Shariah disclosure within the framework of the Shariah governance system in Islamic banks in Indonesia and Malaysia with the observation period in 2009. He focused on disclosure of the Shariah supervisory board and zakat. He found the disclosure of both of them was very limited. Ardhanareswari 
(2017) conducted a study on two Islamic public banks, namely BNI Syariah and BRI Syariah. GCG Disclosures are focused on the disclosure of GCG principles which include transparency, accountability, responsibility, independence and fairness and equality. $\mathrm{He}$ found that the implementation of BRI Syariah GCG and its disclosure can be seen that BRI Syariah has implemented GCG with 'GOOD' although there are several items/indicators of disclosure that are not included in the corporate governance/GCG report.

This study is supposed to examine more in the implementation of GCG in Islamic banks in Indonesia. This research is a developmental research from Ardhanareswari (2017), Darmadi (2013) and Abdullah et al. (2013). The observation period in this study is newer, by which 2015-2017. The disclosure scope of Islamic governance is focused on SSB activities, zakat performance, and disclosure of non-halal income. The dimensions of other GCG disclosures are almost the same as the dimensions of GCG disclosure in banks generally.

\section{Literature Review}

\subsection{Agency theory}

Agency theory explains that agency relations arise when one or more people (principals) employ other people (agents) to provide a service and then delegate decision- making authority to the agent ( Jensen \& Meckling, 1976). He further defines agency relations as follows.

We define an agency relationship as a contract under which one or more persons (the principal(s)) engage another person (the agent) to perform some service on their behalf which involves delegating some decision-making authority to the agent. If both parties to the relationship are utility maximizes, there is good reason to believe that the agent will not always act in the best interests of the principal.

Differences in interests between managers and shareholders will lead to conflict which is commonly referred to agency conflict. Jensen \& Meckling (1976) states that companies that separate management functions from ownership functions will be vulnerable to agency conflict. The causes of the conflict include the decision-making that relates to two things, such as: (1) fund seeking activities and (2) decision-making, concerning how the funds are invested. Agency conflicts or often referred to as agency problems can be minimized by an oversight mechanism that can align these interests so that agency costs arise. 
Agency problems raise agency costs (Jensen \& Meckling, 1976) which consist of:

1. The monitoring of expenditure by the principle, which the cost of supervision issued by the principal to oversee the behavior of agents in managing the company.

2. The bounding expenditure by the agent (bounding cost), which is the cost incurred by the agent to ensure that the agent does not act which is detrimental to the principal.

3. The Residual Loss, which is a decrease in the level of principal and agent utility because of the agency relationship.

\subsection{The concept of good corporate governance}

Shleifer \& Vishny (1996) define corporate governance as a model/set of rules for institutional practical development to protect investors from managerial opportunistic behavior and entrepreneur spirit. Corporate governance is a series of mechanisms that can protect minorities (outside investors/minority shareholders) from exploration conducted by managers and controlling shareholders (insider) with an emphasis on legal mechanisms. Hasan \& Butt (2009) stated that corporate governance can be interpreted as a philosophy and mechanism related to the creation of value for shareholders. In this case corporate governance requires processes and structures that facilitate through the management of the company in such a way that ultimately can guarantee the protection of individuals and all stakeholders. Kaihatu (2006) suggests that the essence of corporate governance is to improve the company performance through supervision or monitoring of management performance and the existence of management accountability to other stakeholders, based on the framework of prevailing rules and regulations.

\subsection{The concept of islamic governance disclosure}

The development of GCG is also important for companies that run their businesses based on Islamic law principles. Lewis (2005) in Muneeza \& Hassan (2014) states that it is difficult to reveal who first introduced Shariah corporate governance. In Arabic literature there is no specific phrase found about it. Shariah corporate governance is a concept that was present in the 19th century after the birth of Islamic banks and Islamic finance. The increasing number of companies that must comply with Shariah requires the formulation of rules dealing with corporate governance that are in line with Islamic law. Muneeza \& Hassan (2014) revealed that the Shari'ah corporate governance was developed from 
Islamic law. The goal is not only to work for the benefit of shareholders and stakeholders, but also to thank God and benefit the community. Ginena (2014) states that "shari'ah over Allah governance is the overall system that manages the conformity of Islamic banks and IFIs to the precepts of shari'ah pertaining to commercial transactions in all activities."

Bhatti \& Bhatti (2010) describe Islamic Corporate Governance (ICG) as follows; ICG seeks to devise ways in which economic agents, the legal system, and corporate governance can be directed by moral and social values based on Shariah laws. Its supporters believe that all economic, corporate, and business activities should be based on an ethnoreligious paradigm, with the sole aim being the welfare of individuals and society as a whole. In many ways, ICG pursues the same objectives as conventional Corporate Governance, but within the religious based moral codes of Islam. However, there is currently no clear unified understanding of 'corporate governance' under Islamic financial law; a model of ICG may be proposed by reconciling the objectives of Shariah laws with the stakeholder model of corporate governance.

Shariah governance models in Islamic financial institutions are still not existing ( $Z$. Hasan, 2010). There are at least five (5) Shariah governance system implementation models, for instance reactive approach (applied in the UK and Turkey), passive approach (applied in Saudi Arabia), minimalist approach (applied in Bahrain, Dubai, and Qatar), pro-active approach (applied in Malaysia), and interventionist approach (applied in Pakistan). Several international institutions issued standards and principles regarding to GCG, such as the OECD, IFSB (Islamic Financial Services Board), IFI (Islamic Financial Institution), and AAOIFI (Accounting and Auditing Organization for Islamic Financial Institution). AAOIFI adopted the Statement on Governance Principles for Islamic Financial Institutions (Ginena, 2014). The implementation of GCG for Shariah commercial banks in Indonesia including its disclosure refers to Bank Indonesia Regulation Number 11/33/PBI/2009 which has prevailed since January 1, 2010.

Based on the description above, it can be concluded that the Islamic Governance Disclosure (IGD) referred to in this study is the disclosure of the implementation of GCG in Islamic banks based on the applicable provisions. The dimensions that differentiate between GCG and IGD disclosures include disclosure of the existence of the Shariah supervisory board, zakat performance, non-halal income, and other disclosure dimensions. This study seeks to uncover in detail the application of ERs to Islamic banks in Indonesia during year 2015-2017 observation period. 


\section{Method}

\subsection{Research design}

Research that has been carried out is an exploratory research that aims to examine more deeply the implementation of Islamic governance disclosure (IGD) in Islamic public banks in Indonesia. The data used is secondary data derived from annual reports, especially in the section on Islamic governance.

\subsection{Research population and sample}

The population in this study is Islamic public banks in Indonesia. In this study, the researcher uses purposive sampling method. The criteria used are the availability of annual reports online for three years of observation and commercial banks having assets of more than 20 billion rupiah by December 31, 2017. The last criteria is used because Shariah commercial banks that have large assets should carry out broader information disclosure. The observation period is three years, started from 2015 to 2017.

\subsection{Focus of research}

The focus of this research is the emergency department in Islamic public banks in Indonesia. The ED dimension was developed from Abdullah et al. (2013) and based on Bank Indonesia Regulation Number 11/33/PBI/2009. There are several items of disclosure of Islamic governance with the following operational indicators.

TABLE 1: Description of Islamic Governance Disclosure dimension.

$\begin{array}{lll}\begin{array}{l}\text { Nb. Disclosure Dimension } \\ \text { 1. }\end{array} & \begin{array}{l}\text { Operational Indicator } \\ \text { general Summary }\end{array} & \begin{array}{l}\text { on GCG Islamic commercial bank implementation } \\ \text { on }\end{array} \\ \begin{array}{ll}\text { Disclosure of Shariah Supervisory } \\ \text { Board (SSB) }\end{array} & \begin{array}{l}\text { a. SSB Report } \\ \text { b. Duties and Responsibilities } \\ \text { c. Remuneration }\end{array} \\ & \text { SSB member's background } \\ & \text { d. Membership and certification } \\ & \text { e. Educational background } \\ & \text { f. Experience } \\ & \text { Activities } \\ & \text { g. SSB meetings }\end{array}$


Nb. Disclosure Dimension

\begin{tabular}{|c|c|c|}
\hline & & h. Shariah audit \\
\hline & & i. Shariah compliance procedure \\
\hline 3. & Disclosure of SSB's report & a. Title \\
\hline & & b. Report recipient \\
\hline & & $\begin{array}{l}\text { c. Opening paragraph (clear objectives of the } \\
\text { agreement) }\end{array}$ \\
\hline & & $\begin{array}{l}\text { d. The paragraph scope that explains the nature of the } \\
\text { work performed }\end{array}$ \\
\hline & & $\begin{array}{l}\text { e. A clear statement that the management of Islamic } \\
\text { banks is responsible for complying with Shariah rules } \\
\text { and principles }\end{array}$ \\
\hline & & $\begin{array}{l}\text { f. Confirmation that SSB has conducted appropriate } \\
\text { testing, procedures and review }\end{array}$ \\
\hline & & In general \\
\hline & & Transactions and agreements \\
\hline & & $\begin{array}{l}\text { Compliance with the Shariah basis for the allocation of } \\
\text { investment accounts }\end{array}$ \\
\hline & & Income (legitimate/prohibited) \\
\hline & & Zakat compliance \\
\hline & & g. The Sharia opinion includes matters relating to \\
\hline & & Contracts, transactions and agreements \\
\hline & & Fair profit and loss allocation \\
\hline & & Income (legitimate/prohibited) \\
\hline & & Zakat \\
\hline & & h. Report on violations of Shari'ah compliance (if any) \\
\hline & & i. SSB reports must be signed by all SSB members \\
\hline & & j. Date of report \\
\hline & & $\begin{array}{l}\text { Additional disclosures: ratification of SSB for financial } \\
\text { statements }\end{array}$ \\
\hline 4. & Disclosure of Zakat & a. Statement of the source and use of zakat \\
\hline & & b. Policy on Zakat \\
\hline & & c. Amount of Zakat \\
\hline & & d. Beneficiaries of Zakat \\
\hline & & $\begin{array}{l}\text { e. Ratification of SSB for the calculation and distribution } \\
\text { of zakat funds }\end{array}$ \\
\hline & & f. The method of calculating zakat \\
\hline 5. & Disclosure of non-halal income & a. Description of non-halal income \\
\hline & & b. Use of non-halal income \\
\hline
\end{tabular}




\subsection{Technique in collecting and analyzing data}

The data obtained in this study uses the documentation method. Documentation sheets (check list) were developed from previous researchers (Abdullah et al., 2013) to describe the implementation of Islamic governance in Islamic banks in Indonesia. Data analysis method used is descriptive statistical analysis and content analysis. Descriptive statistical analysis is used to describe Islamic governance disclosure in the form of data of mean, minimum, maximum, and others. Content analysis is developed from applicable regulations and opinions from previous researchers.

\section{Result and Discussion}

\subsection{Findings}

This research has been carried out to describe the application of Islamic governance disclosure to Islamic banks in Indonesia. Four Islamic banks were chosen to represent the first bank to be established, the largest bank of assets, and Islamic banks to be progressively developed. Islamic banks in question are Bank Mualamat, Bank Syariah Mandiri, BNI

Syariah, and BRI Syariah. The four Islamic banks have assets of more than 20 billion rupiah by December 31, 2017. The observation period is three years, started from year 2015 to 2017. Table 2 shows a summary of the financial performance of the research sample for 3 years.

TABLE 2: Summary of Islamic Bank Financial Performance from year 2015 to 2017.

\begin{tabular}{|c|c|c|c|c|}
\hline $\begin{array}{l}\text { No. } \\
\text { Bank }\end{array}$ & $\begin{array}{l}\text { Financial Performance Indicators } \\
\text { luamalat }\end{array}$ & 2015 & 2016 & 2017 \\
\hline 1. & Return on Assets (ROA) & 0.20 & 0.22 & 0.11 \\
\hline 2. & Return on Equity (ROE) & 2.78 & 3.00 & 0.87 \\
\hline 3. & Net Income Margin (NIM) & 4.09 & 3.21 & 0.21 \\
\hline 4. & Non-performing Financing (Gross) & 7.11 & 3.83 & 4.43 \\
\hline 5. & Non-performing Financing (Net) & 4.30 & 1.40 & 2.75 \\
\hline 6. & Operating Expense Ratio (OER) & 97.41 & 97.76 & 97.68 \\
\hline 7. & Financing to Deposit Ratio (FDR) & 90.30 & 95.13 & 84.41 \\
\hline 8. & Capital Adequacy Ratio (CAR) & 12.00 & 12.74 & 13.62 \\
\hline 9. & The amount of zakat distributed (IDR/million) & 12.533 & 13.002 & 15.150 \\
\hline 10. & The amount of zakat received (IDR/million) & 12.533 & 13.002 & 15.150 \\
\hline 11. & Zakat performance & 100 & 100 & 100 \\
\hline 12. & The amount of assets (IDR/billion) & 57.141 & 55.786 & 61.697 \\
\hline
\end{tabular}




\begin{tabular}{|c|c|c|c|c|}
\hline \multicolumn{4}{|c|}{ Bank Syariah Mandiri } & 2017 \\
\hline 1. & Return on Assets (ROA) & 0.56 & 0.59 & 0.59 \\
\hline 2. & Return on Equity (ROE) & 5.92 & 5.81 & 5.72 \\
\hline 3. & Net Income Margin (NIM) & 6.54 & 6.75 & 7.35 \\
\hline 4. & Non-performing Financing (Gross) & 6.06 & 4.92 & 4.53 \\
\hline 5. & Non-performing Financing (Net) & 4.05 & 3.13 & 2.71 \\
\hline 6. & Operating Expense Ratio (OER) & 94.78 & 94.12 & 94.44 \\
\hline 7. & Financing to Deposit Ratio (FDR) & 81.99 & 79.19 & 77.66 \\
\hline 8. & Capital Adequacy Ratio (CAR) & 12.85 & 14.01 & 15.89 \\
\hline 9. & The amount of zakat distributed (IDR/million) & 31.285 & 22.766 & 24.636 \\
\hline 10. & The amount of zakat received (IDR/million) & 22.850 & 24.321 & 26.029 \\
\hline 11. & Zakat performance & 136.92 & 93.60 & 94.65 \\
\hline 12. & The amount of assets (IDR/billion) & 70.370 & 78.832 & 87.940 \\
\hline \multicolumn{5}{|c|}{ BNI Syariah } \\
\hline 1. & Return on Assets (ROA) & 1.43 & 1.44 & 1.31 \\
\hline 2. & Return on Equity (ROE) & 11.39 & 11.94 & 11.42 \\
\hline 3. & Net Income Margin (NIM) & 8.25 & 8.32 & 8.10 \\
\hline 4. & Non-performing Financing (Gross) & 2.53 & 2.94 & 2.89 \\
\hline 5. & Non-performing Financing (Net) & 1.46 & 1.64 & 1.50 \\
\hline 6. & Operating Expense Ratio (OER) & 89.63 & 86.88 & 87.62 \\
\hline 7. & Financing to Deposit Ratio (FDR) & 91.94 & 84.57 & 80.21 \\
\hline 8. & Capital Adequacy Ratio (CAR) & 15.48 & 14.92 & 20.14 \\
\hline 9. & The amount of zakat distributed (IDR/million) & 12.786 & 15.741 & 18.383 \\
\hline 10. & The amount of zakat received (IDR/million) & 14.963 & 17.369 & 19.299 \\
\hline 11. & Zakat performance & 85.45 & & \\
\hline 12. & The amount of assets (IDR/billion) & 23.017 & 28.314 & 34.822 \\
\hline
\end{tabular}

\section{BRI Syariah}

\begin{tabular}{llccc} 
1. & Return on Assets (ROA) & 0.77 & 0.95 & 0.51 \\
\hline 2. & Return on Equity (ROE) & 6.33 & 7.40 & 4.10 \\
\hline 3. & Net Income Margin (NIM) & 6.66 & 6.67 & 5.84 \\
\hline 4. & Non-performing Financing (Gross) & - & - & - \\
\hline 5. & Non-performing Financing (Net) & 3.89 & 3.19 & 4.72 \\
\hline 6. & Operating Expense Ratio (OER) & 93.79 & 91.33 & 95.24 \\
\hline 7. & Financing to Deposit Ratio (FDR) & 84.16 & 81.47 & 71.87 \\
\hline 8. & Capital Adequacy Ratio (CAR) & 13.94 & 20.63 & 20.29 \\
\hline 9. & The amount of zakat distributed (IDR/million) & 4.242 & 6.998 & 8.799 \\
\hline 10. & The amount of zakat received (IDR/million) & 4.279 & 7.423 & 8.933 \\
11. & Zakat performance & 99.19 & 94.25 & 98.50 \\
12. & The amount of assets (IDR/billion) & 24.230 & 27.687 & 31.543
\end{tabular}


Bank Syariah Mandiri is the largest Islamic commercial bank in Indonesia with total assets of 87,940 billion rupiah by December 31, 2017. Bank Muamalat Indonesia which is the first Islamic bank in Indonesia only has assets of 61,697 billion rupiah. The total assets of BNI Syariah and BRI Syariah are almost the same in the range of 30 billion rupiah. Bank Syariah Mandiri is currently an Islamic bank with the largest market share in the Islamic banking industry. The market share includes assets, third party funds and financing. Market share of assets per December 2017 is 20.73\%, Third Party Funds 23.27\% and Financing $21.24 \%$.

Table 2 also provides data that BNI Syariah is an Islamic bank in Indonesia which has the best profitability performance for three years (2015-2017) among the four Islamic banks that were sampled in this study. The ratio of BNI Syariah return on assets (ROA) is 1.31 in 2017 and is greater than the ROA of Bank Muamalat which is only 0.11 or Bank Syariah Mandiri of 0.59 and BRI Syariah 0.51. The performance of zakat shows that Bank Muamalat is the best, because it gets a score of 100 . This means that the amount of zakat funds received is directly distributed entirely. Bank Syariah Mandiri receives the most zakat funds among four other Islamic banks, which is more than 20 billion over three years. This is because BSM has LAZ itself and can manage zakat funds independently. While other Islamic banks are only zakat collectors or zakat collection counterpart, they must cooperate with LAZ or social foundations owned by banks.

Table 3 shows the dual profiles of the Shariah Supervisory Board (SSB) consisting of gender, educational background, and meetings held, and the level of SSB members at the meetings held. By sex, all SSB members of Islamic banks in Indonesia are men. The number of SSB members is 2-3 people. This is in accordance with prevailing regulations. Bank Muamalat and BSM have 3 members of SSB, while BRI Syariah and BNI Syariah only have 2 members of SSB. Most of SSB members have doctoral background. There are 1-2 people who are professor. All SSB members have experience and certification in the Shariah field and are active in the development of Shariah economics in Indonesia. Meetings held by SSB in one year are 12-19 times with a position level above $60 \%$.

TABLE 3: Summary of Shariah Supervisory Board profile.

\begin{tabular}{llcc}
$\begin{array}{l}\text { No. Shariah Supervisory Board Profile } \\
\text { Bank Muamalat }\end{array}$ & 2015 & 2016 & 2017 \\
$\quad$ Gender & & & \\
1. $\quad$ Male & 3 & 3 & 3 \\
\hline 2. $\quad$ Female & 0 & 0 & 0 \\
$\quad$ Educational Background & & & \\
3. $\quad$ S2 (Master) & 0 & 1 & 0 \\
4. S3 (Doctor) & 1 & 2 & 2 \\
\hline
\end{tabular}


No. Shariah Supervisory Board Profile

5. Professor

\section{SSB's Meeting}

6. Frequency

7. Percentage of attendance

Bank Syariah Mandiri

\section{Gender}

1. Male

2. Female

Educational Background

3. S2 (Master)

4. $\mathrm{S} 3$ (Doctor)

5. Professor

SSB's Meeting

6. Frequency

7. Percentage of attendance

BNI Syariah

Gender

1. Male

2. Female

Educational Background

3. $\mathrm{S} 2$ (Master)

4. $\quad$ S3 (Doctor)

5. Professor

\section{SSB's Meeting}

6. Frequency

7. Percentage of attendance

BRI Syariah

\section{Gender}

1. Male

2. Female

Educational Background

3. S2 (Master)

4. S3 (Doctor)

5. Professor

SSB's Meeting

6. Frequency

7. Percentage of attendance

2015

2016

2017

2

0

1

$12 \quad 12 \quad 12$

$75 \quad 89 \quad 100$

00

(1)

$+2$

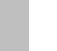




\subsection{The practice of Islamic Governance Disclosure implementation in Islamic Banks}

Islamic governance disclosure in this study was developed based on the results of Abdullah et al. (2013). He divided the IGD as Shariah governance disclosure and classified it into four. The first is disclosure index dealing with SSB or SSB disclosure index, the second is disclosure index dealing with the SSB report or SSB report disclosure index, the third is disclosure index on zakat or Zakat disclosure index, and the fourth is disclosure of non-halal income. The disclosure index regarding to SSB consists of 9 items of disclosure. The SSB report disclosure index comprises 18 items of disclosure. Zakat disclosure index consists of 6 items of disclosure, while non-halal income disclosure index consists of 2 items. Tables 4-7 display the research findings on the practice of disclosure of Islamic governance in Islamic public banks in Indonesia for the past three years (2015-2017).

Information related to Islamic Governance Disclosure was obtained from the annual reports of each Shariah commercial bank for three years, and there are several chapters, namely SSB report and SSB opinion, SSB profile, Corporate Governance, and Corporate Social Responsibility (CSR). Data was also obtained from the disclosure of the remuneration and non-zakat income. Each Shariah commercial bank has different annual report characteristics, including disclosures regarding to SSB. Information on zakat was obtained in the CSR reporting section.

\subsection{The practice of Islamic Governance Disclosure implementation in Bank Muamalat}

Table 4 shows the practices of the implementation of Bank Muamalat's Islamic Governance Disclosure during 2015-2017. Then, information about the IGD at Bank Muamalat in 2015 was found on a page of SSB statement, nine pages on SSB section in the Corporate Governance chapter, two pages on SSB profile, and 19 pages on CSR reports. Whereas in 2016 consisted of seven pages on SSB report, one page on SSB statement, fourteen pages on SSB sub-section in the Corporate Governance chapter, 3 pages on SSB profile, and 37 pages on CSR report. While in 2017 consists of four pages on SSB report, four pages on SSB profile, fourteen pages on SSB section in the Corporate Governance chapter, and twenty two pages on CSR report.

Bank Muamalat achieved an IGD index as many as 0.78 in 2015, 0.81 in 2016 and only got 0.69 in 2017. Bank Muamalat experienced a slight decrease of IGD index in 
2017. In more detail, the SSB disclosure index obtained by Bank Muamalat was 0.89 or $89 \%$ for the last three years. Bank Muamalat SSB report disclosure index in 2015 was 0.78 or $78 \%, 0.72$ or $72 \%$, in 2016 , and only 0.61 or $61 \%$ in 2017 . Bank Muamalat did not disclose the involvement of SSB in determining zakat management policies. This happened because the management of zakat was not carried out by the company, but was done by Baitulmal Muamalat which has its own Shariah Supervisory Board.

Bank Muamalat's zakat disclosure index was 50\% in year 2015 and 2017. Bank Muamalat did not disclose zakat policy in detail including the method of calculating zakat and endorsement from SSB. Zakat funds were reported to CSR reports. It is because company's and employee's ZIS funds were used to carry out CSR activities. In addition, the company also budgeted specifically for the purpose of CSR activities. In 2016, there were 10 pages which provided information on the distribution of the company's and employees' ZIS funds, and including non-ZIS funds. ZIS was distributed through Baitulmal Muamalat (BMM) and other LAZ.

TABLE 4: The practice of Islamic Governance Disclosure implementation in Bank Muamalat Praktik.

\begin{tabular}{|l|l|c|c|c|c|}
\hline No. & Dimension of Disclosure & $\begin{array}{c}\text { Number of } \\
\text { Item }\end{array}$ & $\mathbf{2 0 1 5}$ & $\mathbf{2 0 1 6}$ & $\mathbf{2 0 1 7}$ \\
\hline 1. & General Summary of GCG & 1 item & 1 & 1 & 1 \\
\hline 2. & SSB Disclosure & 9 items & 8 & 8 & 8 \\
\hline 3. & SSB Report Disclosure & 18 items & 14 & 13 & 11 \\
\hline $4 . \quad$ & Zakat Disclosure & 6 items & 3 & 4 & 3 \\
\hline 5. & Non-Halal Income Disclosure & 2 items & 2 & 2 & 2 \\
\hline & Number of Items Disclosed & $\mathbf{2 8}$ & $\mathbf{2 8}$ & $\mathbf{2 5}$ \\
\hline & The number of items that should be disclosed & $\mathbf{3 6}$ & $\mathbf{3 6}$ & $\mathbf{3 6}$ \\
\hline & Islamic Governance Disclosure Index & $\mathbf{0 . 7 8}$ & $\mathbf{0 . 7 8}$ & $\mathbf{0 . 6 9}$ \\
\hline
\end{tabular}

\subsection{The practice of Islamic Governance Disclosure implementation in Bank Syariah Mandiri}

Information on the implementation of the IGD at Bank Syariah Mandiri was obtained from annual reports which were spread out in several sections including the SSB report, SSB profile, SSB sub-section on the Corporate Governance chapter, and CSR report section. In 2015 there was a page of SSB report, 3 pages on the SSB subsection on the Governance chapter, a page of SSB profile, and thirteen pages of CSR reports. In 2016 there were 4 pages of SSB reports, a page of SSB opinion, four pages in the SSB sub-section on the Governance section, two pages of SSB profile and twelve pages of CSR reports. Whereas in 2017, there were four pages of SSB reports, three pages 
of SSB sections in Corporate Governance, two pages of SSB profile, and seven pages of CSR reports. All in all, it can be seen that the information revealed becomes more comprehensive from year to year.

Bank Syariah Mandiri achieved an IGD index score of 0.78 or 78\% in 2015 and 2017 while in 2016 the highest index score was 0.81 or $81 \%$. In more detail, Bank Syariah Mandiri obtained an index score of SSB disclosure as many as 100\% during 2015-2017. Bank Syariah Mandiri SSB report disclosure index was 0.72 or $72 \%$ in 2015 and 2017. While in 2016 the index reached 78\%. This is because BSM did not disclose SSB involvement in zakat management and all SSB members did not sign on the SSB report, SSB opinion, or on the annual report/company financial report.

Bank Syariah Mandiri zakat disclosure index was 0.67 or $67 \%$ for the last three years. BSM did not disclose the approval of SSB in the determination of zakat policy and no information was found dealing with the method of calculating zakat funds obtained from companies and employees. However, BSM was able to reveal information about the management of zakat in more detail than other Islamic banks. At least 4-5 pages were prepared by BSM to uncover zakat management in more detail, both regarding to sources of funding, distribution of zakat funds, beneficiaries, and other important information. Employee's ZIS funds were reported on CSR reports. There was a special section describing the receipt and distribution of ZIS through BSM Laznas. BSM was also able to disclose information about non-halal income. There was a special section describing non-halal acceptance. Non-halal income in BSM is called benevolence fund. Reported number of receipts, beneficiaries, and distribution programs.

TABLE 5: The practice of Islamic Governance Disclosure implementation in Bank Syariah Mandiri.

\begin{tabular}{|c|c|c|c|c|c|}
\hline No. & Dimension of Disclosure & $\begin{array}{l}\text { Number of } \\
\text { Item }\end{array}$ & 2015 & 2016 & 2017 \\
\hline 1. & General Summary of GCG & 1 item & 1 & 1 & 1 \\
\hline 2. & SSB Disclosure & 9 items & 9 & 9 & 9 \\
\hline 3. & SSB Report Disclosure & 18 items & 12 & 13 & 12 \\
\hline 4. & Zakat Disclosure & 6 items & 4 & 4 & 4 \\
\hline \multirow[t]{4}{*}{5.} & Non-Halal Income Disclosure & 2 items & 2 & 2 & 2 \\
\hline & \multicolumn{2}{|l|}{ Number of Items Disclosed } & 28 & 29 & 28 \\
\hline & \multicolumn{2}{|c|}{ The number of items that should be disclosed } & 36 & 36 & 36 \\
\hline & \multicolumn{2}{|l|}{ Islamic Governance Disclosure Index } & 0.78 & 0.81 & 0.78 \\
\hline
\end{tabular}




\subsection{The practice of Islamic Governance Disclosure implementation in BNI Syariah}

The practice of implementing BNI Syariah's Islamic Governance Disclosure can be seen in SSB disclosures through SSB Reports, SSB profiles, sub-sections of SSB and subsections of non-zakat income in the Corporate Governance chapter, and CSR reports. In 2015, BNI

Syariah revealed SSB information in four pages of SSB reports, thirteen pages in the SSB subsection on the Governance chapter, two pages of SSB profiles, and twenty six pages of CSR reports. In 2016, SSB disclosure consisted of two pages of SSB reports, nine pages in the SSB sub-section in the Corporate Governance chapter, two SSB profile pages, and forty pages of CSR reports. While in 2017, SSB disclosure comprised three pages of SSB reports, nine pages of SSB sections in Corporate Governance, three pages of SSB profiles, and thirty pages of CSR reports.

The IGD index of BNI Syariah was 0.78 in 2015 and 2017, and 0.81 in 2016. In more detail, the SSB disclosure index of BNI Syariah was 1.00 or $100 \%$ for last three years. The BNI Syariah's SSB report disclosure index was $0.72,0.76$, and 0.72 , respectively, during year period 2015 to 2017. The zakat disclosure index of BNI Syariah was 0.67 during year period 2015-2017. Similar to BSM, BNI Syariah did not disclose SSB involvement in zakat management, and all SSB members did not sign the SSB report or SSB opinion, as well as financial reports or annual reports.

Corporate and employee Zakat funds for BNI Syariah were reported on CSR reports. There was a special section describing the receipt and distribution of ZIS through Hasanah Titik Foundation and also in collaboration with LAZ Dompet Dhuafa to distribute ZIS funds. There were two pages of reports on receipt and distribution of zakat. BNI Syariah also specifically revealed non-zakat income in 2015-2016.

TABLE 6: The practice of Islamic Governance Disclosure implementation in BNI Syariah.

\begin{tabular}{|c|c|c|c|c|c|}
\hline Nb. & Dimension of Disclosure & $\begin{array}{l}\text { Number of } \\
\text { Item }\end{array}$ & 2015 & 2016 & 2017 \\
\hline 1. & General Summary of GCG & 1 item & 1 & 1 & 1 \\
\hline 2. & SSB Disclosure & 9 items & 9 & 9 & 9 \\
\hline 3. & SSB Report Disclosure & 18 items & 12 & 13 & 12 \\
\hline 4. & Zakat Disclosure & 6 items & 4 & 4 & 4 \\
\hline \multirow[t]{4}{*}{5.} & Non-Halal Income Disclosure & 2 items & 2 & 2 & 2 \\
\hline & \multicolumn{2}{|l|}{ Number of Items Disclosed } & 28 & 29 & 28 \\
\hline & \multicolumn{2}{|c|}{ The number of items that should be disclosed } & 36 & 36 & 36 \\
\hline & \multicolumn{2}{|l|}{ Islamic Governance Disclosure Index } & 0.78 & 0.81 & 0.78 \\
\hline
\end{tabular}




\subsection{The practice of Islamic Governance Disclosure implementation in BRI Syariah}

The practice of implementing IGD in BRI Syariah can be seen in SSB disclosures through SSB Reports, SSB profiles, sub-sections of SSB and sub-sections of non-zakat income in the Corporate Governance section, and the CSR report section. In 2015, there were two SSB opinion pages, two pages in the SSB sub-section on the Corporate Governance chapter, two SSB profile pages, and four CSR report pages. The 2016 Annual Report showed four pages of SSB reports, two SSB opinion pages, eight pages in the SSB subsection on the Corporate Governance chapter, five pages of SSB profiles, and sixteen pages of CSR reports. Corporate and employee ZIS funds were reported on CSR report. The report only described the amount of zakat and distribution through BRI Baitul Maal Foundation (YBM-BRI) and BAZNAS. There was only 1 page found specifically revealed zakat in CSR report in 2015, and added in 2016 to seven pages. Non-halal income was disclosed in CSR report section through the realization of the benevolent fund. It was all reported on the report of the source and use of the benevolent fund notes on the financial statements. Description of non-halal income was found in a page of CSR report in 2015.

IGD Index of BRI Syariah is the most fluctuating index among three other Islamic banks. The IGD index of BRI Syariah was only 0.67 in 2015, increased to 0.83 in 2016, and decreased to 0.69 in 2017. In more detail, the SSB disclosure index of BRI Syariah was 0.89 for last three years. No information related to remuneration and other receipts for SSB was found. The SSB report disclosure index of BRI Syariah was only 0.61 in 2015 and grew by 0.78 in 2016, and deduced to 0.72 in 2017 . The zakat disclosure index of BRI Syariah was 0.50 in 2015 and 2017, rose sharply by 0.83 in 2016.

TABLE 7: The practice of Islamic Governance Disclosure implementation in BRI Syariah.

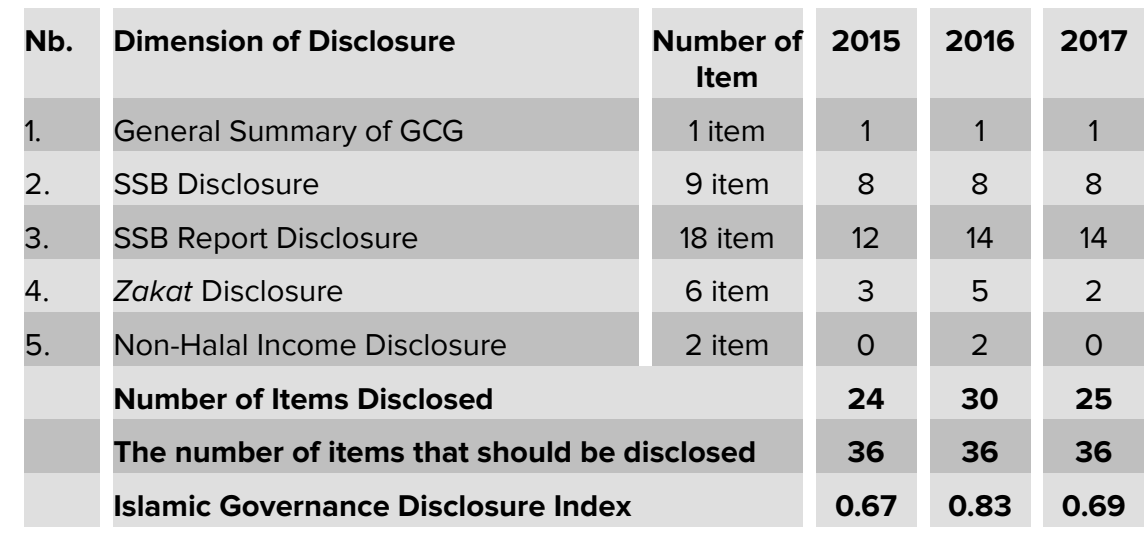




\subsection{The comparison of Islamic Governance Disclosure implementation among Islamic Banks in Indonesia}

The comparison of IGD implementation on Islamic banks in Indonesia during year period 2015 to 2017 can be seen in Tables 4-7. In 2015, the IGD index of BRI Syariah was the lowest while the IGD index of the other three Islamic banks was the same. BRI Syariah did not disclose non-halal income in the annual report of 2015. In 2016, BRI Syariah became an Islamic bank that received the highest IGD index, which was 0.83 . While the other three Islamic banks obtained the same IGD index, which was 0.81 . Islamic banks began to expand disclosures regarding to SSB, zakat, and non-halal income. The IGD of BRI Syariah and Bank Muamalat were lower than the IGD of Bank Syariah Mandiri and BNI Syariah IGD.

For last three years, Bank Syariah Mandiri and BNI Syariah obtained the same score of IGD index, and they became Islamic banks which were considered to be consistent in implementing IGD in Indonesia. Year 2016 was the best year for Islamic banks that can reveal information about SSB, charity, and non-halal income more broadly than in 2015 and 2017. BRI Syariah became an Islamic bank which was less consistent in IGD implementation. Yet, BRI Syariah was still more consistent than Bank Muamalat in terms of IGD implementation.

\section{Discussion}

Hasan (2010) argued that Shariah governance model in Islamic financial institutions is still not existing. Ginena (2014) stated that there are at least five (5) Shariah governance system implementation models, namely reactive approach (applied in the UK and Turkey), passive approach (applied in Saudi Arabia), minimalist approach (applied in Bahrain, Dubai, and Qatar), pro-active approach (applied in Malaysia), and interventionist approach (applied in Pakistan). Several international institutions issued standards and principles dealing with GCG, such as OECD, IFSB, and AAOIFI. AAOIFI adopted the Statement on Governance Principles for Islamic Financial Institutions.

The implementation of GCG for sharia commercial banks including its disclosure in Indonesia refers to Bank Indonesia Regulation Number 11/33/PBI/2009 which prevails by January 1, 2010. Other regulations are BI Circular Letter Nb.12/13/DPbS dated April 30, 2010 concerning about Implementation of Good Corporate Governance for Sharia Commercial Banks and Sharia Business Units. One that must be disclosed is the income 
TABLE 8: Comparison of Islamic Governance Disclosure implementation among Islamic Banks in Indonesia, Year 2015-2017.

\begin{tabular}{|c|c|c|c|c|c|c|}
\hline No. & Dimension of Disclosure & $\begin{array}{c}\text { Number } \\
\text { of Item }\end{array}$ & $\begin{array}{c}\text { Bank } \\
\text { Muamalat }\end{array}$ & $\begin{array}{c}\text { Bank } \\
\text { Syariah } \\
\text { Mandiri }\end{array}$ & $\begin{array}{c}\text { BNI } \\
\text { Syariah }\end{array}$ & $\begin{array}{c}\text { BRI } \\
\text { Syariah }\end{array}$ \\
\hline \multicolumn{7}{|c|}{ Year 2015} \\
\hline 1. & General Summary of GCG & 1 item & 1 & 1 & 1 & 1 \\
\hline 2. & SSB Disclosure & 9 items & 8 & 9 & 9 & 8 \\
\hline 3. & SSB Report Disclosure & 18 items & 14 & 12 & 12 & 12 \\
\hline 4. & Zakat Disclosure & 6 items & 3 & 4 & 4 & 3 \\
\hline 5. & Non-Halal Income Disclosure & 2 items & 2 & 2 & 2 & 0 \\
\hline \multicolumn{3}{|c|}{ Number of Items Disclosed } & 28 & 28 & 28 & 24 \\
\hline \multicolumn{3}{|c|}{ The number of items that should be disclosed } & 36 & 36 & 36 & 36 \\
\hline \multicolumn{3}{|c|}{ Islamic Governance Disclosure Index } & 0.78 & 0.78 & 0.78 & 0.67 \\
\hline \multicolumn{7}{|c|}{ Year 2016} \\
\hline 1. & General Summary of GCG & 1 item & 1 & 1 & 1 & 1 \\
\hline 2. & SSB Disclosure & 9 items & 9 & 9 & 9 & 8 \\
\hline 3. & SSB Report Disclosure & 18 items & 13 & 13 & 13 & 14 \\
\hline 4. & Zakat Disclosure & 6 items & 4 & 4 & 4 & 5 \\
\hline 5. & Non-Halal Income Disclosure & 2 items & 2 & 2 & 2 & 2 \\
\hline \multicolumn{3}{|c|}{ Number of Items Disclosed } & 29 & 29 & 29 & 30 \\
\hline \multicolumn{3}{|c|}{ The number of items that should be disclosed } & 36 & 36 & 36 & 36 \\
\hline \multicolumn{3}{|c|}{ Islamic Governance Disclosure Index } & 0.81 & 0.81 & 0.81 & 0.83 \\
\hline \multicolumn{7}{|c|}{ Year 2017} \\
\hline 1. & General Summary of GCG & 1 item & 1 & 1 & 1 & 1 \\
\hline 2. & SSB Disclosure & 9 items & 8 & 9 & 9 & 8 \\
\hline 3. & SSB Report Disclosure & 18 items & 11 & 12 & 13 & 14 \\
\hline 4. & Zakat Disclosure & 6 items & 3 & 4 & 4 & 2 \\
\hline 5. & Non-Halal Income Disclosure & 2 items & 2 & 2 & 1 & 0 \\
\hline \multicolumn{3}{|c|}{ Number of Items Disclosed } & 25 & 28 & 28 & 25 \\
\hline \multicolumn{3}{|c|}{ The number of items that should be disclosed } & 36 & 36 & 36 & 36 \\
\hline \multicolumn{3}{|c|}{ Islamic Governance Disclosure Index } & 0.69 & 0.78 & 0.78 & 0.69 \\
\hline
\end{tabular}

of non-zakat funds and their use in Islamic banks through the annual report on GCG implementation.

Shariah corporate governance is different from conventional GCG because both objectives are very unique (Alnasser \& Muhammed, 2012; Muneeza \& Hassan, 2014). The Islamic Governance Disclosure (IGD) referred to in this study is the disclosure of the implementation of GCG in Islamic commercial banks based on the applicable provisions. The dimensions that distinguish between GCG and IGD disclosures include disclosure of the existence of the sharia supervisory board (SSB), zakat performance, non-halal 
income, and other disclosure dimensions. This study seeks to uncover in detail the application of IGD on Islamic banks in Indonesia in year period 2015-2017.

The IGD developed in this study is based on the results of Abdullah et al. (2013) and is different from what other researchers have done (Ardhanareswari, 2017; Darmadi, 2013). This study focuses on the IGD that is related to SSB activities and disclosure of zakat and non-zakat income. IGD is measured by the disclosure index, which is the ratio of the number of items that have been disclosed and the number of disclosure items that should be done. IGD comprises 3 main index, such as SSB disclosure index, SSB report disclosure index, zakat disclosure index and non-halal income. Information about IGD is obtained from the annual report and spread into several sections or sub-sections. It was found in the annual report of Islamic banks such as SSB report, SSB profile, SSB section in the Corporate Governance section, and CSR report section. There was a Sharia bank that disclosed information dealing with SSB remuneration and non-zakat income particularly.

The results of the study show that Indonesian Islamic banks have different index scores over the past three years. In general, Islamic banks have performed quite well in disclosing Islamic governance. The lowest index was 0.67 obtained by BRI Syariah in 2015. Islamic banks have revealed a lot of information about SSB profiles and activities and the performance of zakat and non-halal income. SSB profiles can be found easily because Islamic banks presented them well. Educational background, experience, certification, and affiliation or involvement with other financial institutions are presented fairly. Islamic banks also disclosed the activities carried out by SSB in detail. Meetings and attendance of SSB meetings members are presented well. Islamic Banks have also fulfilled the regulations regarding to GCG reporting, this is seen in the Islamic bank's GCG report which is very detailed and informative, in accordance with the existing guidelines.

There were several items of disclosure that were still relatively low. It can be seen on SSB report disclosure index and zakat disclosure index. Islamic Banks did not clearly disclose information dealing with SSB involvement with zakat performance. The management of zakat by Islamic banks through LAZ companies or in collaboration with LAZ/BAZNAS should involve SSB. SSB can be asked to give argumentation or advice related to zakat management. The amount of zakat funds managed was quite large at an average of 15 billion per year. Each Islamic bank was different in its management. Bank Syariah Mandiri has LAZ that can manage independently. While other Islamic banks were collaboratively partnered with BAZNAS or LAZNAS that were available to distribute zakat they received. This means that Islamic banks are only a unit for collecting zakat through social foundations. In addition, not many Islamic banks required all SSB members to 
sign SSB report documents or SSB opinions and financial reports or annual reports. This is very important to provide information that all members of the SSB know and are responsible for reporting that has been carried out by Islamic banks.

\section{Conclusion}

Based on the research findings and discussion, it can be concluded that;

1. Islamic Banks in Indonesia have implemented good practice of IGD. This can be seen from the IGD index score obtained. The lowest IGD index of Islamic Bank was 0.67 in 2015 achieved by BRI Syariah and the highest index was 0.83 in 2016 achieved by BRI Syariah. IGD Index of BRI Syariah was fluctuating and got the lowest IGD index among other Islamic banks year period 2015 and 2017. The IGD index of Bank Syariah Mandiri and BNI Syariah are the highest and most consistent for three consecutive years.

2. The IGD index of Bank Muamalat Index was 0.78 in 2015, 0.81 in 2016, and 0.69 in 2017, respectively. The IGD index of Bank Syariah Mandiri and BRI Syariah are the most fluctuating index of the other Islamic banks. The IGD index of BRI Syariah was only 0.67 in 2015, increased to 0.83 in 2016, and decreased to 0.69 in 2017.

3. The lowest disclosure item of Islamic governance was the SSB report disclosure index. Islamic Banks did not disclose information dealing with the involvement of SSB in the management of zakat funds received and distributed.

\subsection{Limitations and recommendations}

The limitation of this study is the focus of the measurement of Islamic governance disclosure. The researchers only revealed the practice of IGD in Indonesian Islamic banks which based on SSB activities, zakat performance, and disclosure of non-halal income. This makes the disclosure of governance in Islamic banks more limited. In addition, the researchers did not try to reveal the practice of IGD implementation carried out by all Islamic banks in Indonesia although the observation period is time consuming. Researchers should be able to compare IGD practices by Islamic banks with the largest assets to the lowest assets. Moreover, researchers also only depend on the results of Abdullah et al. (2013). Researchers should be able to combine expert opinions, researchers' arguments, and applicable regulations in Indonesia. 
The recommendations that can be submitted for the next research are the use of different and more comprehensive IGD measurement methods. Researchers only used content analysis to calculate the disclosure index. Subsequent researchers might also relate the extent of IGD disclosures to company profiles, such as financial performance and others. Thus, researchers will find novelty and more robust things. In addition, suggestions that can be given are (a) Islamic Banks can disclose information about SSB involvement in the management of zakat and disclose information on zakat management in more detail; and (b) Islamic Banks can sign all SSB members in SSB report documents or SSB opinions.

\section{References}

[1] Abdullah, W. A. W., Percy, M., and Stewart, J. (2013). Shari'ah disclosures in Malaysian and Indonesian Islamic banks; The Shari'ah governance. Journal of Is/amic Accounting and Business Research, vol. 4, no. 2, pp. 100-131. Retrieved from: https: //doi.org/10.1108/JIABR-10-2012-0063

[2] Alnasser, S. A. S. and Muhammed, J. (2012). Introduction to corporate governance from Islamic perspective. Humanomics, vol. 28, no. 3, pp. 220-231. Retrieved from: https://doi.org/10.1108/08288661211258110

[3] Ardhanareswari, R. (2017). Pelaksanaan dan pengungkapan good corporate governance pada bank umum syariah. Jurnal Law and Justice, vol. 2, no. 1, pp. 66-78.

[4] Arora, A. and Sharma, C. (2016). Corporate governance and firm performance in developing countries: Evidence from India. Corporate Governance, vol. 16, no. 2, pp. 420-436. Retrieved from: https://doi.org/10.1108/CG-01-2016-0018

[5] Asrori. (2014). Implementasi ICG dan Implikasi terhadap Kinerja Bank Syariah. Jurnal Dinamika Akuntansi, vol. 6, no. 1, pp. 90-102.

[6] Bhatti, M. and Bhatti, M. I. (2010). Toward understanding Islamic corporate governance issues in Islamic finance. Asian Politics and Policy, vol. 2, no. 1, pp. 25-38. Retrieved from: https://doi.org/10.1111/j.1943-0787.2009.01165.x

[7] Choudhury, M. A. and Hoque, M. Z. (2006). Corporate governance in Islamic perspective. Corporate Governance: The International Journal of Business in Society, vol. 6, no. 2, pp. 116-128. Retrieved from: https://doi.org/10.1108/14720700610655132

[8] Darmadi, S. (2013). Corporate governance disclosure in the annual report. Humanomics, vol. 29, no. 1, pp. 4-23. Retrieved from: https://doi.org/10.1108/ 08288661311299295 
[9] Djakman, C. D., Siregar, S. V., and Harahap, S. N. (2017). Corporate governance disclosure in Indonesia. Pertanika Journal Social Sciences \& Humanities, vol. 25, no. 4, pp. 1739-1752.

[10] Elghuweel, M. I., Ntim, C. G., Opong, K. K., et al. (2017). Corporate governance, Islamic governance and earnings management in Oman: A new empirical insights from a behavioural theoretical framework. Journal of Accounting in Emerging Economies, vol. 7, no. 2, pp. 190-224. Retrieved from: https://doi.org/10.1108/JAEE-09-20150064

[11] Gandia, J. L. (2008). Determinants of Internet-based corporate governance disclosure by Spanish listed companies. Online Information Review, vol. 32, no. 6, pp. $791-$ 817. Retrieved from: https://doi.org/https://doi.org/10.1108/14684520810923944

[12] Ginena, K. (2014). Shari`ah risk and corporate governance of Islamic banks. Corporate Governance: The International Journal of Business in Society, vol. 14, no. 1, pp. 86 103. Retrieved from: https://doi.org/10.1108/CG-03-2013-0038

[13] Green, D. and Graham, C. (2015). Accountability and independence in corporate governance: An analysis of board disclosures in Canada, in Corporate Governance: Does any Size Fit?, pp. 1-11. Retrieved from: https://doi.org/10.1016/S10417060(05)11001-3

[14] Hasan, A. and Butt, S. A. (2009). Impact of ownership structure and corporate governance on capital structure of Pakistani listed companies. International Journal of Business and Management, vol. 4, no. 2, pp. 50-57. Retrieved from: https://doi. org/10.5539/ijbm.v4n2p50

[15] Hasan, Z. (2010). Regulatory framework of Shariah governance system in Malaysia, GCC countries and the UK. Kyoto Bulletin of Islamic Area Studies, vol. 3, no. 2, pp. 82-115. Retrieved from: https://doi.org/10.1108/17538391111122195

[16] Hassan, M. K. (2012). A disclosure index to measure the extent of corporate governance reporting by UAE listed corporations. Journal of Financial Reporting and Accounting, vol. 10, no. 1, pp. 4-33. Retrieved from: https://doi.org/10.1108/ 19852511211237426

[17] Jensen, M. C. and Meckling, W. H. (1976). Theory of the firm区: Managerial behavior, agency costs and ownership structure. Journal of Financial Economics, vol. 3, no. 4, pp. 305-360.

[18] Kaihatu, T. S. (2006). Good corporate governance dan penerapannya di Indonesia. Jurnal Manajemen Dan Kewirausahaan, vol. 8, no. 1, pp. 1-9. Retrieved from: https: //doi.org/10.9744/jmk.8.1 
[19] Malik, M. S. and Makhdoom, D. D. (2016). Does corporate governance beget firm performance in Fortune Global 500 companies? Corporate Governance: The International Journal of Business in Society, vol. 16, no. 4, pp. 747-764. Retrieved from: https://doi.org/10.1108/CG-12-2015-0156

[20] Muneeza, A. and Hassan, R. (2014). Shari'ah corporate governance: The need for a special governance code. Corporate Governance: The International Journal of Business in Society, vol. 14, no. 1, pp. 120-129. Retrieved from: https://doi.org/10.1108/ CG-02-2011-0015

[21] Ntim, C. G., Opong, K. K., Danbolt, J., et al. (2012). Voluntary corporate governance disclosures by post-Apartheid South African corporations. Journal of Applied Accounting Research, vol. 13, no. 2, pp. 122-144. Retrieved from: https://doi.org/10. $1108 / 09675421211254830$

[22] Nurkhin, A. (2010). Corporate governance dan profitabilitas, pengaruhnya terhadap penungkapan CSR Sosial Perusahaan. Jurnal Dinamika Akuntansi, vol. 2, no. 1, pp. 46-55. Retrieved from: http://journal.unnes.ac.id/index.php/jda

[23] Nurkhin, A., Mukhibad, H., Kiswanto, et al. (2018). The Influence of the implementation of good corporate governance principles to firm performance. Indonesian Journal of Business Finance and Accounting, vol. 1, no. 2, pp. 25-33. Retrieved from: http: //thomson.id/index.php/ijbfa/article/view/24

[24] Nurkhin, A., Wahyudin, A., and Fajriah, A. S. A. (2017). Relevansi Struktur Kepemilikan terhadap Profitabilitas dan Nilai Perusahaan Barang Konsumsi. Jurnal Akuntansi Multiparadigma, vol. 8, no. 1, pp. 35-46. Retrieved from: https://doi.org/10.18202/ jamal.2017.04.7038

[25] Parsa, S., Chong, G., and Isimoya, E. (2007). Disclosure of governance information by small and medium-sized companies. Corporate Governance: The International Journal of Business in Society, vol. 7, no. 5, pp. 635-648. Retrieved from: https://doi. org/10.1108/14720700710827211

[26] Qu, W. and Leung, P. (2006). Cultural impact on Chinese corporate disclosure - A corporate governance perspective. Managerial Auditing Journal, vol. 21, no. 3, pp. 241-264. Retrieved from: https://doi.org/10.1108/02686900610652991

[27] Said, R., Joseph, C., and Mohd Sidek, N. Z. (2017). Corporate governance and Corporate Social Responsibility (CSR) disclosure: The moderating role of cultural values, in Modern Organisational Governance, pp. 189-206. Retrieved from: https: //doi.org/10.1108/S2043-052320170000012013

[28] Shleifer, A. and Vishny, R. W. (1996). A Survey of Corporate Governance. 
[29] Tsamenyi, M., Enninful-Adu, E., and Onumah, J. (2007). Disclosure and corporate governance in developing countries: Evidence from Ghana. Managerial Auditing Journal, vol. 22, no. 3, pp. 319-334. Retrieved from: https://doi.org/10.1108/ 02686900710733170

[30] Wahyudin, A. and Solikhah, B. (2017). Corporate governance implementation rating in Indonesia and its effects on financial performance. Corporate Governance: The International Journal of Business in Society, vol. 17, no. 2, pp. 250-265. Retrieved from: https://doi.org/10.1108/CG-02-2016-0034

[31] Wibowo, E. (2010). Implementasi Good Corporate Governance di Indonesia. Jurnal Ekonomi Dan Kewirausahaan, vol. 10, no. 2, pp. 129-138. 